Contents List available at VOLKSON PRESS
Multidisciplinary Inclusive Education, Management
and Legal Services (MIEMLS)
Journal Homepage: https://topicsonsocialdevelop.com
DOI: $10.26480 /$ ismiemls.01.2018.25.26

\title{
SMALL SIGHT ON MORALITY PENALIZATION AND CHINESE TRADITIONAL CULTURE
}

\author{
Mo Xie, Ma Hui, Wu Zhendong \\ ${ }^{1}$ College of Arts and Law, Wuhan University of Technology, Wuhan Hubei, China \\ ${ }^{2}$ Institute of population research, Peking University, Beijing Haidian District, China \\ *Corresponding Author Email: starrktovey@163.com
}

This is an open access article distributed under the Creative Commons Attribution License, which permits unrestricted use, distribution, and reproduction in any medium, provided the original work is properly cited.

\section{ARTICLE DETAILS ABSTRACT}

\section{Article History:}

Received 26 June 2018 Accepted 2 July 2018 Available online 1 August 2018
It is found that China's morality penalization differs from the West in obligation requirements of individuals. That ours makes use of the influence of our traditional culture to maintain regime indicates the contradicts existing in our morality penalization and reminds us of paying more attention to the differences between the West and our history in the course of weighing and borrowing the related regulations in the future.

\section{KEYWORDS}

Morality penalization, Confucian thought, Restriction of criminal law.

\section{INTRODUCTION}

Morality penalization, referred to one chapter of the book Coincidences and Differences of Law Culture of China and the West by Fan Zhongxin, introduces the distinctions between Western law and Chinese traditional law in respect of morality penalization.

Criminal laws of Europe and America, involving numerous contents of moral responsibilities, believe the fundamental purpose of law is to protect social groups' life from disorder and to enhance social harmoniousness from the perspectives of society standard and obligation. China's law has a great difference between historical soil and present situation compared with that of Europe and America. Based on that the author would like to have a brief consideration of morality penalization in China.

\section{OUTLINE OF CHINA'S MORALITY PENALIZATION}

\subsection{Recognition}

From history perspective, there were rationality and appropriation in traditional morality penalization of China. Reasonableness means it was in conformity with the development of traditional Politics, economy and culture of China. Morality legalization plays an irreplaceable role in bolstering political governance, providing a stable environment for economic development and facilitating cultural prosperity. Moreover, it is an inevitable outcome of the traditional law.

In terms of law itself, morality-penalization law takes consanguineous family as the core of its group, thus making individuals lose its independence. Moralized law, combining economic and political inequalities with consanguineous relationships, covers manmade factors in inequality and naturalizes them to make the masses convince, and integrates moral principles into autocracy, which are against democracy [1].

\subsection{Reasons}

In view of politics, the link between morality penalization and emperor's governance is exactly natural. Authorities used political powers to proactively promote morality penalization. Replacement of dynasty made each emperor have a clear idea that the dynasty could not last a long time only through repression of harsh rules. Therefore, they listed morality of willpower into law to realize the control over people in secret. Based on that, the government idea of "virtue dominates while punishment subordinates" which has been being advocated by the Confucianism had become the regime thought since Han dynasty.

In view of culture, China's traditional law itself is part of traditional culture. The past China was an ethical society in which moral principles of Confucian thought directed the development of economy, politics, literature and art, etc., and prevailed in the lives of civilians. Morality penalization needed a social atmosphere where moral norms dominate to develop itself, and the moral feelings accumulating in the traditional culture very catered to this need and offered it a good moral environment [2].

\section{NEW STATUS QUO OF CHINA'S PRESENT MORALITY PENALIZATION}

As mentioned in the beginning, the contemporary western legal traditions are established in Social Standard. On the contrary, our legal system built since the establishment of new China only requires individuals to take these Negative Responsibilities for society, such as not killing persons, not stealing anything, etc. The author makes the following contrasts via the introduction by Mr. Fan.

\subsection{Sabotaging or Protecting Others from Saving the Dangers of Other People or Yours}

The act of stopping other people from saving someone else is usually deemed as immorality but not a crime in China. It is seen as a crime in Western countries that anyone does not request or decline other people to save himself/herself or someone else in danger or prevent such lifesaving. In their opinion, personal life health not only belongs to yourself, but belongs to the entire society or country, and individuals have no right to give up or waste it alone. But in China suicide is normally thought of having 
no direct damage to others and society, and as a slight immoral behavior.

\subsection{Guilty for Exploiting Helpless People and Violent Crime}

In terms of moral principles, the two crimes of Exploiting Helpless People and Violence all belong to terrible behaviors of giving up morality and justice for profits. Though no any direct hazards happen to social security and order, it has a serious breach of the requirements of social righteousness or justice and is an erosion to good customs and practices. Our country mentions the basic principle of opposing the act of exploiting helpless persons and violence, while in practice we merely treat them as immoral behaviors and at most requires relate persons to take responsibility of civil law instead of illegality.

The present condition tells what is different from cases of other morality penalization is that in China the two crimes above mentioned are criticized from the level of morality in most situations but have not been increased to the height of law.

Actually, Chinese traditional legislation, which is dominated by Confucian thought, attaches great importance to that individuals should have obligations to support and protect families and national regimes, but puts few emphases on obligations to life order of social community. As a result, it is hard for the individuals and social groups cultivated and influenced by the traditional Confucianism to keep away from the restraints of this idea in the existing legal system. In addition, since traditional Confucian thought of China relies on the reception of favoring more families and relatives and national political powers than group of individuals, more consideration is needful for the issue of which is more important---western ideas borrowing or our traditions inheritance.

\section{COLLISION BETWEEN MODESTY OF CRIMINAL LAW AND OMNIPOTENT IDEA}

\subsection{Little Yueyue Case and Disputes behind}

On the $13^{\text {rd }}$ day of October 2011 in Foshan, Guangdong Province, a twoyear girl called Little Yueyue was run down by a minibus accidentally and rolled over twice while crossing over the road. Subsequently, another car passed on the body of her once more. More than 10 people, who went by the girl within 7 minutes, but the woman, a scraps collector, turned a blind eye to her. Later, a hot debate provoked as a result of it.

For this, there were two public opinions. Some people appealed to criminalize the behavior of not rescuing those in mortal danger, according to Guangzhou Daily and other media. While the legal experts thought it was not appropriate to make such behavior illegal because Little Yueyue case is more about the morality [3].

The dispute, whether the moral issues incurred due to the case should be penalized, lets restriction of criminal law replay a game with omnipotent ideas.

\subsection{Value of Modesty of Criminal Law}

Omnipotent thought of criminal law is one of mainstreams of Chinese traditional criminal law, which is easily found in the legislation ideas of Criminalizing Improprieties that were advocated by ancient Chinese. The idea of criminal law omnipotence in the traditional criminal law at the time of new China establishment is still deep-rooted in today's society.

Modesty of criminal law means restricting penalty seriously and locking it in the agreed limit and scope. The penalty, as a supplementary scheme for the efficiency that other legal sanction approaches cannot make, ought to be deemed as the ultimate line of defence for regulating acts of illegality and crime, so as to produce the effect of criminal law omnipotence.

Modesty of criminal law can be applied to criminal matters only the following two aspects are met. First, criminal legislation is supposed to be in line with the aim of criminal law and can be adopted to properly restrict people's freedom of exercising rights only the purpose to protect public interests or social security is true. Second, criminal legislation ought to have a certain proportion of measurement and take these issues-----legal interests with what nature is infringed and what the infringement degree is, into consideration so as to determine whether to execute penalty or what penalty should be carried out [4].

Modesty of criminal law actually is an intervention and restraint to omnipotence of criminal law and is a relief to morality penalization [5]. For instance, the dispute, caused by Little Yueyue Case, appeals to criminalize the act of neglecting to save life, these indifferent foot passengers actually did not have any behavior infringing others' legal interest, so how can they be penalized? But penalizing them has no any benefit to society's stability except creating a limit to citizens' personal freedom. Such penalization will have criminal law overused, and have moral principles confused with criminal law so that the defence function of it will be ignored.

\section{THINKING TO MORALITY PENALIZATION}

Article I of Criminal Law says that the aim of it is to punish criminals and protect people. And it was formulated based on the Constitution and our specific experience and practical situation of fighting against crimes, which indicates that legislation of criminal law is strict and relevant and cannot be expanded without enough considerations [6].

That the traditional law culture still functions in the present China should not be neglected. The legal system, attaching great importance to subjective ideas of people, had stepwise formed since Dong Zhongshu made it up to the peak height of justice in the Han Dynasty by adjudicating suits in line with the spirit of "Spring and Autumn"and other Confucianist classics.

It is obvious that there is a contradiction existing between the both. However, it is found that, after having a profound idea of the influence of Chinese traditional Confucian thought on law, China's traditional legal system ultimately developed into the mainstream of morality given priority over penalty, which values civilization but underestimates retribution and has an incline of purposeful and educational penalty. In reality, such mainstream offers a good guide for the modern rules of law, which directs penalty as a tool to realize the duty-bound and just purposes within its acceptable spectrum.

Punishment from the military essentially is the most powerful violent tool that is used to resist "enemies" and safeguard groups to survivei. After evolution, it was determined as a social standard, favoring more state than individuals and having the trends of social defence.

Our morality penalization has been always permeating in legislation of criminal law and justice in the long term. Distinctions between the West basically were brought about by the influence of Confucian thought. It follows that our traditional culture is more powerful than the Western legal technologies and ideas in the aspect of influences. Applying the traditional culture in a good manner and correcting the deviations likely to happen can better facilitate the existing system of criminal law to develop.

\section{REFERENCES}

[1] Xuecui, Z., Fulong, L. 2012. Interpreting Morality Legalization from Legislation Perspective [A]. Legal System and Society, February (Part I).

[2] Cunsheng, Y. 2007. Ethicality: Humane Dimension of Law [A]. Legal Science (Journal of Northwest University of Political Science and Law), 1.

[3] Mingliang, W. 2014. Analysis on Excessive Criminalization from Moral Panics Perspective [A]. Legal Research, the 9th issue.

[4] Dafu, Z., Li, Y. 2013. How to Revoke "Omnipotence of Criminal Law" in Criminal Policies [A]. Legal System and Society, January (Part II).

[5] Yanhong, L., Gairan, M. 2012. Subjectivism Principles of Criminal Law: Cultural Causes, Realistic Manifestation and Precise Hazards [A]. Forum of Politics and Law, 30 (3). 